Volume 12, Nomor 2, November 2020, pp 203-214 Copyright (C) 2017

Jurnal Akuntansi, Program Studi Akuntansi, Fakultas Ekonomi, Universitas Kristen

Maranatha. ISSN 2085-8698 | e-ISSN 2598-4977. http://journal.maranatha.edu

\title{
Pengaruh Pengungkapan Laporan Tahunan Periode 2014- 2018 dan Ukuran Perusahaan Terhadap Harga Saham. (Studi Kasus Pada Perusahaan BUMN yang Sahamnya Terdaftar Dalam IDX BUMN20)
}

\author{
Demetrius Kunto Wibisono ${ }^{1}$ \\ Fakultas Ekonomi Program Studi Magister Manajemen Universitas Katolik Parahyangan \\ (Jalan Merdeka No.30 Bandung) \\ Demetriuskunto@gmail.com \\ Esther Yolanda ${ }^{2}$ \\ Fakultas Ekonomi Program Studi Akuntansi Universitas Katolik Parahyangan \\ (Jalan Ciumbuleuit No.94 Bandung) \\ Estherlnd@gmail.com
}

\begin{abstract}
This study aims to find out how the influence of Disclosure of Financial Statements for the period 2014 - 2018 and Company Size on the Stock Price. This case study was conducted by taking a sample of companies list on IDX BUMN20. This study uses the hypothesis testing method using IBM SPSS Statistics Subscription version 23. Based on the results of the study found that an increase in average disclosure in all companies listed on the IDX, in other words, an increase in awareness of the management of companies listed on the IDX to report both financial and non-financial information to the public. In addition, companies listed on the IDX are increasingly obedient to the policies made by the regulator (OJK) related to the disclosure of financial statements. The Annual Disclosure Variable does not partially affect the company's stock price, this is due to differences in the research sector and research year. Partially, the variable size of the company has an influence on stock prices, this is because investors are interested in investing in companies that have large assets and have a large market capitalization because they are considered more profitable. Simultaneously, the Annual Report Disclosure variable and company size variables have a significant effect on stock prices.
\end{abstract}

Keywords: Annual Report Disclosure, Company Size, and Stock Price. 


\begin{abstract}
Abstrak
Penelitian ini bertujuan mencari bagaimana pengaruh Pengungkapan Laporan Keuangan periode 2014 - 2018 dan Ukuran Perusahaan terhadap Harga Saham. Studi kasus ini dilakukan dengan mengambil sampel perusahaan yang terdaftar di IDX BUMN20. Penelitian ini menggunakan metode hipotesis testing dengan menggunakan alat bantu IBM SPSS Statistic Subscription version 23. Berdasarkan hasil penelitian didapat bahwa terjadi peningkatan rata-rata disclosure di seluruh perusahaan yang terdaftar di BEI, dengan kata lain, terjadi peningkatan kesadaran dari manajemen perusahaan yang terdaftar di BEI untuk melaporkan baik informasi keuangan maupun informasi non keuangan kepada masyarakat. Selain itu perusahaan yang terdaftar di BEI semakin taat terhadap kebijakan yang dibuat oleh regulator (OJK) terkait pengungkapan laporan keuangan. Variabel Pengungkapan Laporan Tahunan secara parsial tidak mempengaruhi harga saham perusahaan, hal ini disebabkan karena adanya perbedaan pada sektor penelitian dan tahun penelitian. Secara Parsial, variabel Ukuran Perusahaan memberikan pengaruh terhadap Harga Saham, hal ini disebabkan karena investor tertarik melakukan investasi di perusahaan yang memiliki aset yang besar serta memiliki market capitalization yang besar karena dianggap lebih menguntungkan. Secara bersamaan, variabel Pengungkapan Laporan Tahunan dan variabel ukuran perusahaan memberikan pengaruh yang signifikan terhadap harga saham.
\end{abstract}

\title{
Kata Kunci: Pengungkapan Laporan Tahunan, Ukuran Perusahaan, dan Harga
} Saham.

\section{Pendahuluan}

Dunia bisnis di Indonesia saat ini menunjukkan perkembangan yang sangat pesat sehingga para pelaku pasar dituntut untuk bertindak dengan efektif dan efisien guna beradaptasi dan mempunyai kekuatan dalam bersaing. Perkembangan yang pesat tersebut salah satunya dipengaruhi oleh persaingan global. Persaingan global memberikan tekanan pada seluruh perusahaan untuk menjadikannya lebih unggul dibandingkan perusahaan pesaingnya. Ekonomi global saat ini menjadikan persaingan semakin ketat pada setiap elemen bisnis seperti kualitas produk, inovasi, pelayanan, dan lain-lain.

Selain persaingan global, ekonomi global juga memuat krisis global secara bersamaan. Kedua aspek tersebut samasama menuntut setiap perusahaan untuk bertahan dalam dunia bisnis. Krisis ekonomi global merupakan suatu peristiwa di mana pada saat itu sebagian besar lini bisnis di pasar dunia mengalami penurunan yang tajam dan salah satu Negara yang terkena imbas akibat penurunan ekonomi dunia itu adalah Indonesia. Amerika Serikat, sebagai negara superpower yang memiliki kendali ekonomi di pasar dunia pun tidak luput dari kehancuran besar ini. Hal ini ditandai dengan tergoncangnya bursa saham di Amerika Serikat karena Lehman Brother dinyatakan bangkrut pada bulan September 2008. Goncangan yang terjadi tidak hanya melanda bursa saham Amerika Serikat, namun hampir di seluruh dunia. Tidak ketinggalan , pada saat itu guncangan pun terjadi di Bursa saham kawasan Asia Pasifik. Bursa saham Hongkong, Jepang, China, Australia, India, Singapura, dan Taiwan pun mengalami penurunan hampir mencapai $10 \%$. Tidak terkecuali bursa saham di kawasan Timur Tengah dan Eurasia. Pada saat terjadinya Economic Crash di tahun 2008, Para pelaku pasar di bursa Wall Street mengalami kerugian yang sangat besar, dan hal ini berimbas juga ke pasar modal yang ada di Indonesia, dimana para investornya 
sebagian besar adalah investor asing. Bursa Efek Indonesia pada waktu itu sempat melakukan penghentian perdagangan (Trading Halt) dikarenakan penurunan yang terjadi pada saat itu sangat besar, yaitu mencapai 30\% (Nuh, 2008 : 75).

Dalam Persaingan di pasar global, perusahaan atau para pelaku bisnis berlomba-lomba untuk mencapai tujuan bisnisnya, salah satunya memperluas pasar supaya dapat bersaing di pasar global, dan kemajuan perusahaan di suatu Negara dapat mendukung perekonomian di Negara tersebut. Salah satu sektor perusahaan yang berpengaruh langsung terhadap pertumbuhan ekonomi suatu negara adalah perusahaan milik negara, atau lebih dikenal dengan BUMN (Badan Usaha Milik Negara). BUMN sendiri adalah perusahaan yang secara kemilikan modalnya dimiliki oleh pemerintah, baik seluruh modalnya atau sebagian modalnya. Salah satu indikator yang sekaligus menjadi faktor penentu dari pertumbuhan ekonomi sebuah perusahaan adalah bagaimana perusahaan dapat memperoleh jumlah investor yang ditargetkan untuk mencapai objektif perusahaan. Untuk dapat memperoleh target investor yang diinginkan, sebuah perusahaan harus mendaftarkan saham perusahaannya pada bursa efek suatu negara. Di Indonesia BUMN yang gopublic dan menjual sahamnya kepada masyarakat diwajibkan untuk mendaftarkan perusahaannya terlebih dahulu di BEI dan secara periodik diwajibkan melaporkan laporan keuangannya, hal ini dilakukan supaya masyarakat serta para investor bisa memperoleh laporan tahunan yang dimiliki perusahaan tersebut dengan mudah. Laporan tahunan merupakan laporan perkembangan dan pencapaian yang berhasil diraih organisasi dalam periode satu tahun yang didalamnya terdapat Laporan Kinerja perusahaan dan Laporan Keuangan perusahaan selama satu tahun serta disajikan dengan data yang akurat. Akibat terjadinya krisis keuangan global pada tahun 2008, investor sangat berhati- hati pada saat menginvestasikan sejumlah modalnya di perusahaan. Analisa Laporan Keuangan perusahaan merupakan salah satu bentuk penggambaran awal kondisi perusahaan, tingkat kelangsungan hidup perusahaan, dan menilai bagaimana manajemen perusahaan melaporkan seluruh kinerja perusahaan secara relevan, transparan, dan mudah dipahami.

Sebagai upaya memastikan sebuah perusahaan negara maupun perusahaanperusahan lain yang terdaftar di BEI sudah menyampaikan laporan tahunan dengan baik, maka dibutuhkan suatu standar atau aturan tertentu yang mengatur pelaporan tahunan dari kinerja setiap perusahaan. Dengan adanya standar atau aturan tersebut maka setiap perusahaan diharapkan dapat menyampaikan laporan tahunan sesuai aturan, yang nantinya akan dipublikasikan kepada publik mengenai kinerja perusahaannya. Keadaan tersebut dapat terealisasi jika masing-masing perusahaan dapat mematuhi peraturan dan standar yang berlaku. Jika perusahaan negara yang terdaftar dalam BEI menyesuaikan pelaporannya dengan aturan yang berlaku, diharapkan publik dan para investor paham serta tertarik untuk membeli saham perusahaan negara tersebut sehingga perusahaan negara mampu untuk bersaing dan mempertahankan harga sahamnya dalam persaingan ekonomi. Berdasarkan uraian diatas, maka timbul pertanyaan yang dijabarkan dalam 3 rumusan masalah, yaitu:

1. Bagaimana pengaruh pengungkapan laporan tahunan periode 2014 - 2018 terhadap harga saham perusahaan?

2. Bagaimana pengaruh ukuran perusahaan terhadap harga saham perusahaan?

3. Bagaimana pengaruh Pengungkapan Laporan Tahunan periode 2014 - 2018 dan ukuran perusahaan terhadap harga saham perusahaan? 
Adapun tujuan dari penelitian ini adalah:

1. Menganalisis pengaruh pengungkapan laporan tahunan periode 2014 - 2018 terhadap harga saham perusahaan.

2. Menganalisis pengaruh ukuran perusahaan terhadap harga saham perusahaan.

3. Menganalisis pengaruh pengungkapan laporan tahunan periode 2014 - 2018 dan ukuran perusahaan terhadap harga saham perusahaan.

\section{Kerangka Teoritis dan Hipotesis}

\section{Investasi}

Menurut Kamus Besar Bahasa Indonesia (KBBI), investasi dapat diterjemahkan sebagai kegiatan penanaman uang atau modal dalam suatu perusahaan atau proyek untuk tujuan mendapatkan keuntungan. Kegiatan investasi menurut ilmu ekonomi adalah kegiatan membeli barang modal serta peralatan produksi untuk menambah barang modal yang kemudian akan digunakan sebagai alat untuk menambah produksi barang dan jasa di masa depan. menyebutkan bahwa investasi sebagai pengeluaran pemerintah untuk membeli barang-barang modal dan peralatanperalatan produksi dengan tujuan untuk mengganti dan terutama menambah barangbarang modal yang akan digunakan untuk memproduksi barang dan jasa di masa yang akan datang. Dalam bukunya, Reilly dan Brown (2003:5) mengatakan bahwa .investasi adalah komitmen. satu. dollar dalam. satu periode tertentu, akan mampu memenuhi kebutuhan investor di masa yang akan datang dengan: (1) waktu Dana Tersebut Akan digunakan, (2) tingkat inflasi yang terjadi (3) ketidakpastian kondisi ekonomi di masa yang akan datang

Menurut Fahmi dan Hadi (2009:7) investasi dibagi menjadi dua golongan besar, yaitu investasi langsung dan investasi tidak langsung. Investasi langsung sendiri adalah seorang investor memberikan modalnya pada perusahaan tersebut yang ditandai dengan pembelian surat-surat berharga yang dikeluarkan perusahaan tersebut, dan berharap mendapatkan imbal hasil berupa pendapatan dari deviden dan capital gains. Sedangkan invetasi tidak langsung diartikan sebagai penjualan suratsurat berharga milik perusahaan melalui perusahaan investasi yang memiliki peran sebagai perantara antara perusahaan dan investor. Syarat perusahaan dapat menjadi perantara salah satunya perusahaan tersebut harus terdaftar secara resmi di OJK.

Fischer dan Jordan (2005:65) dalam bukunya mendefinisikan risiko investasi sebagai ketidakpastian dalam kemungkinan distribusi return. Jenis-jenis risiko yang umumnya dihadapi oleh perusahaan yaitu: 1. Business Risk (Risiko Bisnis) Adalah resiko akibat naik turunnya pendapatan perusahaan sejalan dengan penjualannya, hal tersebut digambarkan dalam financial report serta ada kaitannya dengan perubahan permintaan pasar dan keadaan makro ekonomi. 2. Financial Risk (Risiko Finansial) adalah resiko yang berhubungan dengan pendapatan dan dapat memengaruhi risiko bisnis dan struktur finansial perusahaan serta dikaitkan dengan financial leverage perusahaan. 3. Inflation Risk / Purchasing Power Risk (Risiko Inflasi / Penurunan Daya Beli) yaitu resiko yang dihubungkan dengan adanya potensi bahwa tingkat pengembalian investasi sebanding dengan peningkatan biaya hidup. 4. Interest Rate Risk (Risiko Suku Bunga) adalah resiko yang dihubungkan dengan penurunan pendapatan perusahaan karena kerugian nilai portofolio yang diakibatkan oleh perubahan suku bunga. 5. Social Risk (Risiko Sosial) adalah resiko yang dapat terjadi akibat perubahan kondisi sosial di masyarakat yang mengakibatkan perusahaan merubah kebijakan perusahaannya. 6. Foreign Exchange Risk (Risiko Nilai Tukar) adalah resiko yang terjadi akibat adanya perubahan pada nilai tukar mata uang dunia, dan berpotensi mengakibatkan penurunan ROI (Return on 
Investment). 7. Political Risk (Risiko Politik) adalah resiko yang terjadi akibat adanya campur tangan pemerintah luar negeri terhadap kegiatan perusahaan maupun perekonomian dalam negeri yang mengakibatkan lingkungan bisnis menjadi tidak kondusif. (Fischer \& Jordan, 2005:70).

\section{Pasar Modal}

Pengertian pasar modal menurut UndangUndang Pasar Modal No.8 Tahun 1995 adalah kegiatan yang bersangkutan dengan penawaran umum dan perdagangan surat kepemilikan perusahaan yang diterbitkan oleh perusahaan. Pasar modal sendiri dapat diartikan sebagai pasar untuk berbagai instrumen keuangan jangka panjang yang bisa diperjualbelikan, baik dalam bentuk hutang, ekuitas (saham) instrumen derivatif, maupun instrumen lainnya.

Sunariyah (2011:12) menyebutkan bahwa ada beberapa jenis pasar modal, diantaranya:

1. Pasar Perdana (Primary Market) dimana perusahaan dapat menawarkan saham terlebih dahulu kepada pemodal sebelum saham tersebut ditawarkan di pasar sekunder.

2. Pasar Sekunder (Secondary Market), Penjualan saham di pasar sekunder dapat dilakukan apabila saham perusahaan tersebut sebelumnya sudah ditawarkan di pasar perdana.

3. Pasar Ketiga (Third Market) yaitu merupakan tempat dimana transaksi saham dilakukan diluar bursa efek, dapat dikoordinir oeh Perserikatan Perdagangan Uang dan Efek serta diawasi dan dibina oleh Lembaga Keuangan.

4. Pasar Keempat (Fourth Market) Jenis pasar modal ini merupakan bentuk perdagangan efek antar pemegang saham ketika ada pemegang saham yang ingin menjual sahamnya dengan nominal yang besar, biasanya dilakukan oleh pemegang saham mayoritas.

\section{Badan Usaha Milik Negara (BUMN)}

Menurut Undang-Undang Nomor 19 Tahun 2003 Tentang Badan Usaha Milik Negara, definisi Badan Usaha Milik Negara, yang selanjutnya disebut BUMN adalah Badan usaha yang seluruhnya atau sebagian besar modalnya dimiliki oleh negara melalui penyertaan secara langsung yang berasal dari kekayaan negara yang dipisahkan. Dalam pembukaan Undang-undang tersebut, BUMN diartikan sebagai salah satu pelaku kegiatan ekonomi dalam perekonomian nasional berdasarkan demokrasi ekonomi. Menurut penjelasan Pasal ayat (3), pemisahaan kekayaan negara untuk dijadikan penyertaan modal negara ke BUMN hanya dapat dilakukan dengan cara penyertaan langsung negara ke BUMN, sehingga setiap penyertaan tersebut harus ditetapkan dengan peraturan pemerintah (PP). Sebagai contoh, PT Kereta Api Indonesia adalah Badan Usaha Milik Negara karena sebagian modal perseroan tersebut berasal dari modal penyertaan langsung di Negara Republik Indonesia. Modal penyertaan berasal dari kekayaan negara yang dipisahkan dan kekayaan yang dipisahkan di sini adalah pemisahan kekayaan negara dari Anggaran Pendapatan dari Belanja Negara (APBN) untuk dijadikan penyertaan modal negara pada BUMN untuk dijadikan modal BUMN (Khairandy, 2013:163).

BUMN sendiri memiliki beberapa fungsi, berdasarkan kutipan yang diambil dari T.Gilarso(2004:194) BUMN memiliki peranan yang cukup penting dalam proses memproduksi berbagai macam barang dan jasa yang kemudian digunakan sebagai alat untuk mewujudkan cita-cita bangsa Indonesia, yaitu kesejahteraan untuk rakyat. BUMN sendiri mencakup beberapa sektor, yaitu sektor keuangan, sektor industry, sektor perkebunan, sektor transportasi dan lain sebagainya. 


\section{Ukuran Perusahaan}

Ukuran perusahaan pada dasarnya adalah kegiatan pengelompokan perusahaan ke dalam beberapa kelompok berdasarkan skala tertentu, diantaranya perusahaan besar, sedang, dan kecil dan didasarkan pada besar kecilnya total aset perusahaan (Suwito \& Herawaty, 2005:136). Penelitian ukuran perusahaan dapat menggunakan acuan besar atau kecilnya asset. Karena total aset perusahaan dapat bernilai lebih besar maka hal ini dapat disederhanakan dengan mentransformasikan ke dalam logaritma natural (Gozali, 2016:96). Ukuran perusahaan juga dapat dihitung dengan ratarata total pendapatan bersih untuk tahun yang bersangkutan sampai beberapa tahun kedepan. Dalam hal ini jika penjualan lebih besar dibandingkan biaya variabel dan biaya tetap, maka dapat diperoleh jumlah keuntungan sebelum pajak. Sebaliknya, jika terjadi kondisi dimana penjualan lebih kecil dibandingkan biaya variabel dan biaya tetap maka perusahaan dapat menderita kerugian (Brigham \& Houston, 2010:9). Perusahaan dengan ukuran besar memiliki keunggulan yaitu perusahaan tersebut akan lebih mudah untuk mendapatkan pendanaan dari luar, sepeti pinjaman, sehingga perusahaan tersebut memiliki kesempatan lebih besar dalam memenangkan persaingan dan bertahan dalam industri (Sugiono \& Christiawan, 2013:239). Sartono (2010:249) juga menyebutkan bahwa perusahaan besar yang sudah wellestablished dapat lebih mudah memperoleh tambahan modal dari penjualan sahamnya di pasar modal.

\section{Laporan Keuangan}

Berdasarkan pedoman dari SAK, salah satu proses Pelaporan yang Lengkap adalah pelaporan Laba Rugi, Neraca, dan Laporan posisi keuangan. Pembuatan laporan keuangan itu sendiri bertujuan untuk menyampaikan informasi mengenai posisi keuangan terhadap para pemangku kepentingan (Stakeholder). Sutrisno (2012:9) mengungkapkan bahwa hasil akhir dari sebuah proses akuntansi ( Laporan laba rugi dan Neraca) adalah berupa penyajian laporan keuangan. UU no 19 tahun 2003 menyatakan bahwa laporan keuangan yang dilaporkan dalam jangka waktu satu tahun disebut dengan laporan tahunan. Fungsi dari laporan tahunan ini adalah memberikan informasi kepada para pemegang saham dan disetujui dalam RUPS. Pihak regulator bursa efek yaitu OJK mewajibkan kepada seluruh emiten di bursa untuk secara rutin melaporkan laporan tahunannya untuk kemudian digunakan para stakeholder dalam pengambilan keputusan. Menurut Suwito dan Herawati (2005:18) salah satu fungsi dari laporan tahunan adalah melaporkan kepada para masyarakat terkait pencapaian perusahaan, dan laporan tahunan ini sebagai sarana pemasaran dalam bentuk tertulis yang dapat menambah nilai jual perusahaan di mata konsumen.

\section{Saham}

Menurut Fahmi (2012:81) Salah satu bukti kepemilikan Modal Pada suatu perusahaan adalah dengan memiliki suatu surat tanda bukti penyertaan kepemilikan modal, dimana pada surat itu tercantum nilai nominal, nama perusahaan, serta diikuti dengan hak dan kewajiban yang jelas untuk setiap pemegangnya, surat tanda bukti kepemilikan modal tersebut biasa disebut dengan saham. Selain itu,ada pendapat lain yang diutarakan oleh Martalena dan Maya (2012:55) yaitu saham adalah instrumen yang yang cukup diminati oleh investor karena dianggap dapat memberikan tingkat keuntungan yang menarik. Saham sendiri dibagi menjadi tiga jenis, yaitu Saham Biasa, Saham Preferen, dan Saham Treasury (Jogiyanto,2007:158). Jogiyanto sendiri menyebutkan bahwa harga saham tersebut harga dapat berubahubah sesuai dengan kondisi pasar (Permintaan dan Penawaran) (2007:167). Harga saham sendiri terdiri dari tiga nilai harga, yaitu Nilai Buku, Nilai Pasar, Nilai Intrinsik. Widoatmojo (2005:54) menyebutkan bahwa ada beberapa jenis 
harga saham, yaitu Harga Nominal, Harga Perdana, Harga Pasar, Harga Pembukaan, Harga Penutupan, Harga Tertinggi, Harga Terendah, Harga rata-rata.

\section{Hipotesis Penelitian}

Penelitian ini akan menguji 3 hipotesis, yaitu:

h1:Pengungkapan laporan keuangan perusahaan periode 2014-2018 memengaruhi harga saham perusahaan.

h2:Ukuran Perusahaan memengaruhi harga saham perusahaan.

h3: Pengungkapan laporan keuangan perusahaan dan ukuran perusahaan secara bersamaan memengaruhi harga saham perusahaan.

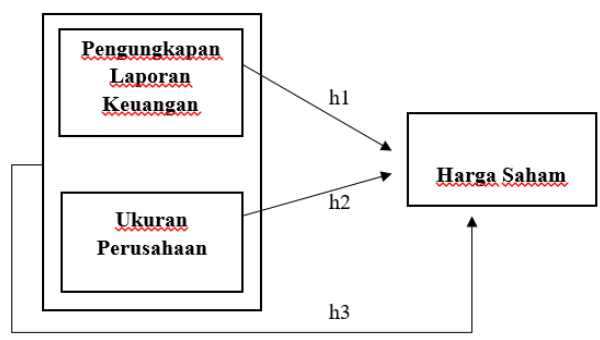

\section{Gambar 1 \\ Model Penelitian \\ Sumber : Olahan Penulis}

\section{Metode Penelitian}

Jenis penelitian yang digunakan dalam penelitian ini adalah Hypotesis Testing dimana penelitian ini menggunakan data sekunder yang berupa laporan tahunan perusahaan. Menurut Davis dan Mukamal (2006:1078), pengujian hipotesis adalah proses yang. digunakan untuk mengevaluasi kekuatan bukti dari sampel dan menyediakan. kerangka. kerja untuk membuat determinasi yang berkaitan dengan populasi, yaitu menyediakan metode untuk memahami seberapa andal salah satu metode dalam memperkirakan temuan yang diamati dalam sample yang diambil dari sebuah populasi. Metode ini digunakan untuk meneliti sejauh mana pengaruh pengungkapan laporan keuangan periode 2014-2018 dan ukuran perusahaan terhadap harga saham.

\section{Populasi dan Sampel}

Teknik pengambilan sampel yang dilakukan dalam penelitian ini adalah dengan metode purposive sampling. Sample penelitian diambil dari perusahaan BUMN yang terdaftar di dalam kategori IDX BUMN20, dan didalam kategori tersebut terdapat 18 perusahaan yang dijadikan sampel untuk mewaliki populasi perusahaan yang terdaftar di bursa efek.

\section{Teknik Pengumpulan Data}

Teknik pengumpulan data adalah dengan teknik literature study, teknik ini digunakan untuk mencari data sekunder dan data yang digunakan adalah laporan tahunan perusahaan pada periode 20142018 yang diambil dari situs resmi Bursa Efek Indonesia.

\section{Tehnik Pengolahan Data}

Pengolahan data yang digunakan dalam penelitian ini yaitu dengan teknik kuantitatif. Laporan Tahunan perusahaan yang telah dikumpulkan kemudian akan diberikan score 1 untuk perusahaan yang menyampaikan laporan tahunan sesuai dengan aturan dan score 0 jika laporan perusahaan yang dilaporkan tidak sesuai dengan aturan.

\section{Hasil Penelitian dan Pembahasan}

\section{Statistik Deskriptif}

Dari 18 perusahaan yang dijadikan sample penelitian dan dengan 90 data pengamatan, didapat perhitungan dengan hasil sebagai berikut. 


\section{Tabel 1 \\ Perhitungan Statistik Deskriptif}

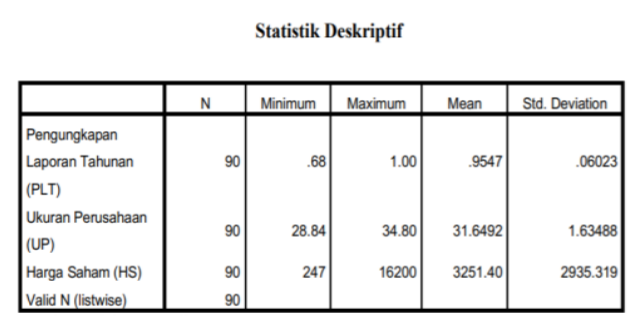

Sumber Tabel: Data Olahan Penulis

Dari tabel diatas didapatkan data yang menggambarkan besar kuantitas nilai minimum, maksimum, mean, dan standar deviasi, dan penjelasan dari tabel diatas adalah sebagai berikut:

1. Score Minimum, Pengungkapan laporan keuangan PT.Wijaya Karya Beton Tbk mendapat score terendah, dengan tingkat kepatuhan sebesar 68\% pada tahun 2017, sedangkan ukuran perusahaan terkecil dimiliki oleh PT. Aneka Tambang Tbk dengan Ln Total Asset sebesar 28.84, dan untuk harga saham terendah dimiliki oleh PT.Elnusa Tbk dengan harga saham sebesar Rp.247.

2. Score Maksimum, sebagian besar perusahaan di BEI mendapatkan score $100 \%$ terkait pelaporan laporan tahunan selama 5 tahun, sedangkan untuk ukuran perusahaan terbesar dimiliki oleh Bank Bri dengan Ln Total Asset 34,80 pada tahun 2018, dan nilai harga maksimum diperoleh oleh PT.Semen Indonesia (SMGR) di tahun 2014 dengan harga penutupan sebesar Rp.16.200.

3. Mean, pada Harga Saham sebesar Rp 3.251,40, Pengungkapan laporan tahunan 0,9547, dan Ukuran perusahaan dengan Ln Total Aset sebesar 31,6492. 47 4)

4. Standard Deviation, pada Harga Saham adalah sebesar Rp 2.935,319, untuk Pengungkapan sebesar 0,06023, dan ukuran perusahaan dengan Ln Total Aset sebesar 1.63488.

\section{Uji Asumsi Klasik}

Pengujian awal data menggunakan model uji Normalitas, Uji Multikolinieritas, Uji Heteroskedastisitas, dan Uji Autokorelasi. Berdasarkan hasil pengujian asumsi klasik, didapatkan bahwa seluruh data memenuhi kriteria uji asumsi klasik, sehingga data tersebut memenuhi syarat untuk menjadi dasar pengujian hipotesis. Pengujian hipotesis akan dilakukan dengan Uji Hipotesis Parsial (t-Test) dan Uji Statistik Simultan $(F-T e s t)$

\section{Uji Hipotesis}

\section{Uji Hipotesis Parsial (t-Test)}

Uji Hipotesis parsial digunakan untuk menunjukkan seberapa jauh pengaruh variabel independen secara parsial terhadap variabel dependennya. Gozali (2016:162) menyebutkan jika nilai signifikansi $<0,05$ maka variabel independen secara parsial mempengaruhi variabel dependen.

Berikut ini adalah hasil uji hipotesis dengan uji parsial

\section{Tabel 2}

\section{Hasil Uji t}

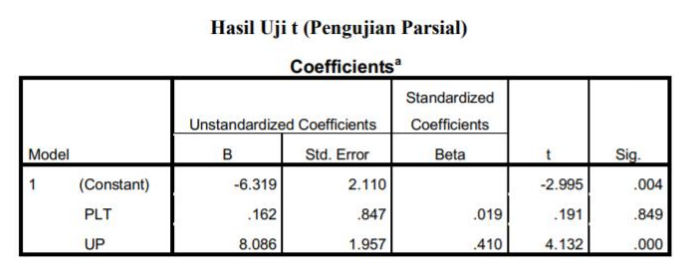

Sumber Tabel : Hasil Olahan Penulis

Berdasarkan tabel diatas, Hasil uji hipotesis menunjukkan bahwa hasil signifikansi Pengungkapan Laporan Tahunan memiliki nilai $0,849>0,05$ (taraf signifikansi penelitian), dan hal ini menyatakan bahwa variabel Laporan Tahunan tidak berpengaruh parsial secara signifikan terhadap Harga Saham. Berdasarkan tabel t dengan $\mathrm{df}=87$ (n-k, 90-3) dan signifikansi 
dua sisi 0,025, memberikan angka 1,98761 dan t hitung PLT dengan angka 0,191 lebih kecil dibandingkan tabel $\mathrm{t}(0,191<$ 1,98761) sehingga memberikan hasil jika H0 diterima dan HA ditolak dan hal ini menunjukkan bahwa semakin besar independensi pengungkapan laporan tahunan maka tidak berarti bahwa harga sahamnya akan naik. Hasil ini sejalan dengan penelitian yang pernah dilakukan sebelumnya oleh Juniadhi (2009:107), dalam penelitiannya ditemukan hasil yang sama yaitu Pengungkapan Laporan Keuangan tidak berpengaruh parsial secara signifikan terhadap harga saham dengan nilai signifikansi 0,472>0,05.

Hasil uji hipotesis untuk variabel Ukuran Perusahaan menunjukkan angka signifikansi $0,000<0,05$ (taraf signifikansi penelitian), sehingga memberikan hasil bahwa variabel Ukuran Perusahaan berpengaruh parsial signifikan terhadap Harga Saham. Berdasarkan tabel t dengan df $=87(\mathrm{n}-\mathrm{k}, 90-3)$ dan signifikansi dua sisi 0,025, memberikan angka 1,98761 dan $\mathrm{t}$ hitung UP 4,132 lebih besar dibandingkan tabel $\mathrm{t}(4,132>1,98761)$ maka hasil tersebut mengartikan bahwa $\mathrm{H} 0$ ditolak dan HA diterima sehingga dapat dikatakan semakin besar ukuran suatu perusahaan maka Harga Saham Perusahaan tersebut akan meningkat. Penelitian lain yang menemukan hasil yang serupa adalah penelitian yang dilakukan oleh Prasetyorini (2013:191), dalam penelitian itu dikatakan ada pengaruh yang signifikan antara ukuran perusahaan terhadap harga saham perusahaan tersebut,dengan nilai sig.t yang didapat adalah sebesar $0,000<0,05$. Prasetyorini mengungkapkan juga bahwa investor akan menangkap sinyal positif jika perusahaan tersebut memiliki ukuran yang besar, dan dikarenakan banyak investor yang yang berminat berinvestasi di perusahaan tersebut, maka harga saham perusahaannya juga akan meningkat.

\section{Uji Statistik Secara Simultan (F-Test)}

Uji ini dilakukan untuk mengukur sejauh mana variabel bebas secara simultan atau bersamaan mempengaruhi varibel terikat, jika nilai probabilitas lebih kecil dari pada $0,05(<0,05)$ maka dapat dikatakan bahwa variabel bebas secara simultan mempengaruhi variabel terikat (Gozali,2006:84).

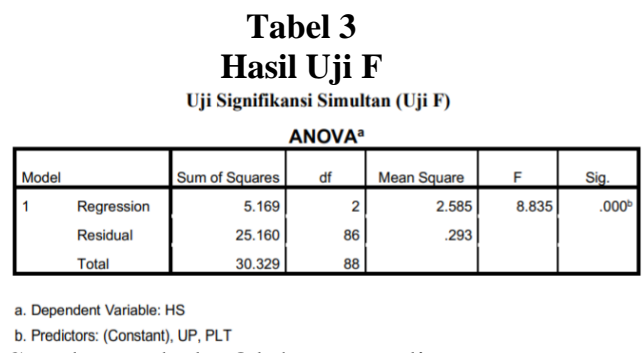

Sumber Tabel : Olahan Penulis

Berdasarkan tabel 3 didapatkan nilai $\mathrm{F}$ sebesar 8,835 dengan nilai signifikansi sebesar 0,000, dari angka ini dapat disimpulkan bahwa variabel Pengungkapan Laporan Tahunan dan Ukuran Perusahaan berpengaruh signifikan secara simultan terhadap Harga Saham dengan signifikansi sebesar $0,000<0,05$. Maka HA diterima, artinya pengungkapan laporan keuangan dan ukuran perusahaan secara simultan memberikan pengaruh terhadap harga saham perusahaan.

\section{Simpulan dan Saran}

\section{Simpulan}

Dari hasil penelitian serta uraian yang telah dijabarkan diatas, maka terdapat variabel independen yang secara langsung tidak memberikan pengaruh signifikan terhadap variabel dependennya, dan berikut ini akan disampaikan kesimpulan akhir dari penelitian ini

1. Tingkat Pengungkapan Laporan Tahunan periode 2014-2018 tidak memberikan pengaruh secara signifikan 
terhadap harga saham. Pendapat ini didasari oleh hasil uji t yang memiliki nilai signifikansi 0,849 (>0,05). Angka tersebut menunjukkan bahwa Pengungkapan Laporan Keuangan secara parsial tidak memberikan pengaruh terhadap harga saham perusahaan.

2. Variabel Ukuran perusahaan mempunyai pengaruh yang positif terhadap Harga Saham, hal ini didasari oleh hasil uji t yang memiliki nilai 0,000 (< 0,05). Nilai tersebut menunjukkan bahwa Harga Saham akan meningkat sejalan dengan ukuran perusahaan. Para investor cenderung berinvestasi di perusahaan yang memiliki ukuran yang besar, karena dianggap dapat memiliki potensi mengembangkan bisnisnya dan memiliki kemampuan bertahan ditengah persaingan global.

3. Secara Simultan, variabel Pengungkapan Laporan Tahunan dan Ukuran Perusahaan memberikan pengaruh signifikan terhadap harga saham, hal ini didasari oleh nilai yang didapat dari Hasil F-test sebesar 8,835 dan nilai signifikansi $0,000(<0,05)$.

\section{Saran}

Melihat dari hasil penelitian yang telah dilakukan, maka ada beberapa saran yang dapat diberikan baik kepada perusahaan, investor, maupun peneliti selanjutnya, adapun saran yang dapat diberikan adalah sebagai berikut:

1. Perusahaan ada baiknya melaporkan laporan tahunannya secara rutin dan transparan kepada publik, hal ini perlu dilakukan agar masyarakat memiliki kepercayaan terhadap perusahaan itu. Selain itu, laporan tahunan perusahaan yang lengkap dan transparan sangat membantu investor untuk mengambil keputusan berinvestasi di perusahan tersebut, terlebih jika perusahaan tersebut memiliki ukuran yang besar. Perusahaan berukuran besar selalu menjadi incaran para investor untuk menginvestasikan dananya, dan ukuran perusahaan dapat terlihat di Laporan Tahunan Perusahaan, sehingga jika laporan yang disajikan memiliki transparansi terutama yang berkaitan dengan nilai aset dan pendapatan, maka perusahaan lebih mudah mendapatkan sinyal positif dari para calon investor yang ingin berinvestasi di Perusahaan tersebut.

2. Untuk para regulator, diharapkan para regulator selalu mengembangkan dan mempertahankan aturan-aturan terkait pelaporan tahunan perusahaan. Hal ini dapat membantu investor untuk mendapatkan laporan tahunan yang sangat sistematis, transparan, dan sesuai dengan kriteria pelaporan sehingga para investor terbantu dalam mengambil keputusan investasi di sebuah perusahaan.

3. Untuk penulis selanjutnya, Penulis selanjutnya diharapkan dapat melakukan penelitian yang lebih mendalam serta spesifik. Penelitian ini hanya membatasi kriteria perusahaan yang terdaftar di IDX BUMN20, sehingga data yang didapat masih cukup minim dan tidak spesifik menggambarkan kondisi di sektor tertentu maupun industri tertentu. Penulis selanjutnya dapat mengembangkan penelitian ini dengan menambah variabel baru dimana data yang diambil lebih spesifik dan mengacu pada sektor tertentu atau industry tertentu, sehingga hasil penelitian selanjutnya dapat memudahkan investor untuk mengambil keputusan jika mereka berinvestasi di satu sektor atau satu industri saja.

\section{Daftar Pustaka}

Ayu, M. (2017). "Pengaruh Kualitas Pengungkapan Informasi terhadap Volume Perdagangan Saham dan Return Saham Studi Empiris pada Perusahaan LQ-45 di BEI." 
Brigham, E. F., \& Dan Houston, J. (2007). "Fundamental of Financial Management". United States of America: Eleventh Edition, Thomson South-Western.

Brigham, \& Houston. (2010). "Dasardasar Manajemen Keuangan (edisi III)". Jakarta: Salemba Empat.

Davis, R. B., \& Mukamal, K. J. (2006). "Hypothesis Testing". In R. B. Davis, \& K. J. Mukamal, "Statistical Primer for Cardiovascular Research" (p. 1078). United States: Circulation.

Fahmi, I., \& Hadi, Y. L. (2009). "Teori Portofolio dan Analisis Investasi". Bandung: Alfabeta.

Fahmi, I. (2012). "Analisis Laporan Keuangan", Cetakan kedua. Bandung: CV Alfabeta.

Fajar, Juniadhi., 2009, "Pengaruh Pengungkapan Laporan Keuangan, Laba Akuntansi, Suku Bunga SBI, dan Uang Beredar terhadap Harga Saham".

http://repository.uinjkt.ac.id/dspace/bit stream/123456789/568/

1/92187PENGARUH\%20PENGUNG KAPAN\%20LAPORA

N\%20KEUANGAN,\%20LABA\%20A

KUNTANSI, $\% 20$ SUK

U\%20BUNGA\%20SBI.

Fischer, D. E., \& Jordan, R. J. (2005).

"Business Essential". New Jersey: Prentice Hall.

Gozali, I. (2016). "Aplikasi Analisis Multivariate dengan Program IBM SPSS 23". Semarang: BPFE Universitas Diponegoro.

Gozali, I. (2010). "Aplikasi Analisis Multivariate dengan Program SPSS". Semarang: UNDIP.

Jogiyanto. (2007)."Teori Portofolio dan Analisis Investasi". Edisi Keenam. Cetakan Pertama. Yogyakarta: PT. BPFE.

Kementerian BUMN. (2015, April 11). Berita: Artikel. "Retrieved from Kementerian BUMN" :http://bumn.go.id/ptpn5/berita/0-

Kompetensi-dan-ManajemenSumber-

Daya-Manusia

Keputusan Ketua Badan Pengawas Pasar

Modal dan Lembaga Keuangan

Nomor: KEP/431/BL/2012 Tentang

Penyampaian Laporan Tahunan

Emiten atau Perusahaan Publik.

(2012). Jakarta: Badan Pengawas Pasar Modal dan Lembaga Keuangan.

Khairandy, R. (2013). "Pokok-Pokok Hukum Dagang”. Yogyakarta: FHUII Press.

Martalena, \& Malinda, M. (2011). "Pengantar Pasar Modal". Edisi Pertama. Yogyakarta: Andi.

Nuh, M. (2008). "Buku 1 Sekretariat Negara. Memahami Krisis Keuangan Global bagaimana harus bersikap?" 75.

Pemerintah Indonesia. (2016, Desember 15). Retrieved from Jaringan Dokumentasi dan Informasi Hukum Kementerian BUMN: http://jdih.bumn.go.id/lihat/19\%20Tah un\%202003

Peraturan perundang-undangan 19 Tahun 2003 tanggal 19 Juni 2003, Tentang Badan Usaha Milik Negara. Jakarta: Kementerian BUMN Indonesia.

Prasetyorini, B. F. (2013). "Pengaruh Ukuran Perusahaan, Leverage, Price Earning Ratio, dan Profitabilitas Terhadap Nilai Perusahaan”. 183196.

Priyastama, R. (2017). “Buku Sakti Kuasai SPSS Pengolahan Data dan Analisis Data”. Yogyakarta: Start Up.

Putranto, A. D., \& Darmawan, A. (2018). "Pengaruh Ukuran Perusahan, Profitabilitas, Leverage, dan Nilai Pasar Terhadap Harga Saham”. Jurnal Administrasi Bisnis (JAB) Vol. 56 No. 1 Maret 2018, 110-118.

Reilly, F., \& Brown, K. C. (2003). "Investment Analysis and Portfolio Management" 7th edition. US: Thomson South-Western Inc. 
Sekaran, U., \& Bougie, R. (2016).

"Research Methods for Business".

United Kingdom: John Wiley \& Sons.

Sugiono, L. P., \& Christiawan, J. Y. (2013).

"Analisa Faktor yang Mempengaruhi

Likuiditas Pada Industri Ritel yang

Terdaftar Pada Bursa Efek Indonesia

Tahun 2007-2012”. Jurnal Business

Accounting Review, Vol. 1, No.2, 298305.

Sunariyah. (2011). "Pengantar Pengetahuan Pasar Modal". Yogayakarta: UPP STIM YKPN.

Suwito, A., \& Herawaty, A. (2005). "Analisis Pengaruh Karakteristik Perusahaan Terhadap Tindakan Perataan Laba yang Dilakukan oleh Perusahaan yang Terdaftar di Bursa Efek Jakarta". SNA VIII Solo, 136146.

T. Gilarso. (2004). "Pengantar Ilmu Ekonomi Makro". Yogyakarta: KANISIUS.

Undang-undang Nomor 8 tahun 1995 tentang Pasar Modal. (1995). Jakarta: Pemerintah Indonesia.

Undang-undang Republik Indonesia Nomor 19 Tahun 2003 Tentang Badan Usaha Milik Negara. (2003). Jakarta: Pemerintah Indonesia.

Undang-Undang Republik Indonesia Nomor 20 Tahun 2008. Jakarta: Pemerintah Indonesia.

Widoatmodjo, S. (2005)."Cara Sehat Investasi di Pasar Modal”. Jakarta: PT. Elex Media Computindo.

www.Idx.co.id 